\title{
In Vivo Induction of Primary DNA Lesions upon Subchronic Oral Exposure to Multi-walled Carbon Nanotubes
}

\author{
GELLÉRT GERENCSÉR, TÍMEA VARJAS, KATALIN SZENDI and CSABA VARGA
}

Department of Public Health, Medical School, University of Pecs, Pecs, Hungary

\begin{abstract}
Comet assay was used for testing the potential genotoxicity of multi-walled carbon nanotubes after ingestion. Three rat strains were treated through oral gavage with 50 $\mathrm{mg} / \mathrm{kg} /$ weekly nanoparticles for 90 days. Induced DNA lesions were studied in lymphocytes at 24 and 48 following the first treatment. This was repeated at the end of the subchronic treatment in lymphocytes as well as peritoneal macrophages. A significant increase in the level of DNA lesions was measured in lymphocytes of Fischer-344 and Long-Evans rats in the first $24 \mathrm{~h}$. Similar results were observed in their macrophages after 90 days. More significant differences were detected in the sensitivities of the strains. Fisher-344 rats proved the most sensitive and Wistar rats the most tolerant to the genotoxic effects of nanotubes. This may also have human relevance as populations with diverse genetic characteristics might present higher or lower susceptibility to the effects of exposure to ingested nanoparticles.
\end{abstract}

The recent introduction of nanotechnology means revolutionary development of nanoproducts. These products are planned for applications in very different fields, from engineering to the food industry and medicine (1-4). As a consequence of their wide use, they inevitably reach the natural environment $(5,6)$, from which the risk of human exposure may also be significant (7). Single- (SW) and multiwalled (MW) carbon nanotubes (CNT) are members of the family of the third carbon allotropes, the fullerenes. Their structural differences can define their toxicological behaviour. Although their potential toxicity has been widely studied, their human health risk is not yet clear (8). Genotoxicity studies were also performed with MWCNTs, involving induction of primary DNA lesions (9-11) and chromosomal aberrations (12, 13). These were mainly in vitro studies measuring very

Correspondence to: Gellért Gerencsér, Szigeti út 12. Pécs, 7624, Hungary. Tel: +36 72536394, Fax: +36 72536395, e-mail: gellert.gerencser@gmail.com

Key Words: Multi-walled carbon nanotube (MWCNT), genotoxicity, oral exposure, comet assay, subchronic, rat. different endpoints with sometimes equivocal outcome. The structure and size range of CNTs are very similar to those of asbestos fibres or fibrils that can initiate mesothelioma and bronchial carcinoma (14). Takagi and co-workers were able to induce mesotheliomas upon intraperitoneal exposure to a welldefined CNT dose range in mice (15). Other in vivo studies refute this mesothelioma-inducing effect (16-18).

As there may be close correlation between carcinogenicity and genotoxicity, we performed a medium-term (subchronic) experiment of the potential genotoxicity of MWCNTs under in vivo conditions. In our experiments, oral exposure (ingestion) was modelled by using oral gavage. Three laboratory rat strains: Fischer-344 (F344), Long-Evans (LE) and Wistar were applied. Peripheral blood lymphocytes and peritoneal macrophages were prepared from the treated animals and DNA strand breaks as biomarkers of genotoxicity were measured in the comet assay (in a singlecell microgel electrophoresis system).

\section{Materials and Methods}

MWCNT samples of technical purity $(10-30 \mathrm{~nm} \times 1-2 \mu \mathrm{m}$, purity: $95-98 \%$ by vol.) were produced by Shenzhen Nanotech, Port Co. Ltd., Shenzhen, China. Nanotubes were successfully dispersed in a carbopol-based semiliquid gel using a magnetic stirrer (19). Three female animals per strain (weight: $300 \mathrm{~g}$; age: 15-16 weeks) were treated orally with $50 \mathrm{mg} / \mathrm{kg}$ nanoparticles (once per week after one day fasting) for 90 days. The animals were obtained from the Departmental Animal House (Medical School, University of Pecs, Pecs), housed in standard polycarbonate cages $(330 \times 160 \times 137 \mathrm{~mm})$, bedded with shavings under laboratory conditions $\left(20-22^{\circ} \mathrm{C}\right.$, humidity $40-60 \%, 12 \mathrm{~h}$ light/dark photoperiod) and fed with standard rodent pellet (CRLT/n standard rodent pellet; Szinbád Kft., Gödöllő, Hungary) and water was provided ad libitum.

DNA lesions (strand breaks) were studied in peripheral lymphocytes at 24 and $48 \mathrm{~h}$ following the first treatment. This measurement was repeated at the end of the subchronic treatment in lymphocytes and peritoneal macrophages. Then the animals were killed and autopsied to search for the presence of CNTs in the peritoneal cavity. Possible macroscopic alterations of organs were also studied. Three untreated animals of the same strains were used as controls. All animal studies were performed in an ethical and humane way under the control of the authorized Ethical Board (number: BA02/2000-16/2011). 
The comet assay was performed as described elsewhere (20) with slight modification. After the lysis step, slides were kept in the electrophoresis buffer for 20 minutes. The electrophoresis lasted $40 \mathrm{~min}$ at $0.46 \mathrm{~V} / \mathrm{cm}$ and $132 \mathrm{~mA}$. Ethidium bromide was used for fluorescent staining. The analyses were performed under fluorescence microscope at $\times 400$ magnification. A total of 50 images per slide were captured and analysed by specific image analysis software (Comet assay IV; Perceptive Instruments Ltd., Bury St Edmunds, UK). Tail moments (TM, based on the area and length of tail, diameter of the head, and relative fluorescence intensities) generated by the program were compared in a MannWhitney $U$-test using SPSS 21.0 software (IBM Corp., Armonk, NY, USA).

\section{Results}

The autopsies did not show any sign of macroscopic lesions of organs nor of nanotube deposition in the peritoneal cavity. During the first $24 \mathrm{~h}$, there was no significant difference in TMs of the Wistar control and treated animals. However, F344 and LE rats showed significantly elevated levels of DNA strand breaks (F344 $p<0.001$; LE $p=0.042)$ within the first $24 \mathrm{~h}$ (Figure 1).

Comparison of the treated strains allows the potentially different sensitivities to be estimated. Figure 1 also shows that F344 rats had a significantly higher level of DNA lesions as compared to both Wistar and LE $(p<0.001)$ strains. The LE strain, however, proved more sensitive as compared to Wistar $(p<0.001)$.

Peripheral blood samples were also taken from the animals $48 \mathrm{~h}$ after the first treatment. The comet assays presented discrepant results at that time, since a significant difference in TMs was only found between the control and the treated animals $(p=0.002)$ of the Wistar group (Figure 2). For the Wistar group, the mean TMs of the treated group significantly differed only from the 48-h control but not from the 24-h control. Comparing the three treated groups to each other, statistically significant differences were detected in two cases: LE vs. F344 $(p=0.021)$ and Wistar $v s$. LE $(p<0.001)$ (Figure 2).

At the 90th day of treatment, the comet assay was repeated both in blood lymphocytes and peritoneal macrophages. Lymphocytes did not show any significant difference between controls and treated animals in any strain (Figure 3). Significant differences were, however, observed between the treated groups of some strains (LE vs. F344, $p=0.009$; Wistar $v s$. LE, $p=0.002$ ). No significant difference was observed between Wistar and F344 strains.

Figure 4 summarises the results obtained from peritoneal macrophages. CNT-treated F3344 $(p=0.001)$ and LE $(p=0.013)$ groups but not the Wistar group differed significantly compared to the respective control groups. Statistically significant differences were observed both between Wistar and F344 $(p<0.001)$ and Wistar and LE $(p=0.01)$, but not LE vs. F344 (Figure 4).

\section{Discussion}

Considering the sensitivity of lymphocytes, the Wistar group seemed to exhibit the lowest since significant difference were only obtained at the 48-h sampling. If the absorption of CNTs is slower in this strain, the later effect is explicable. The other two strains proved to be more sensitive to the MWCNT administration but the effect was limited to the first $24 \mathrm{~h}$ in these animals. That DNA strand breaks could not be detected later in these strains may be explained by either their having effective repair or rapid elimination capabilities.

The lack of subchronic effects in all the three strains suggests a highly effective elimination of nanotubes from the organism, or the presence of efficient mechanisms of adaptation.

If nanotubes leave the gastrointestinal system and reach the peritoneal cavity, the possible genotoxic effects of continuous oral exposure can be followed in peritoneal macrophages. At the end of the 90-day study, the comet assay of peritoneal macrophages from the two more sensitive strains (F344 and LE) delivered positive results while those from the Wistar group did not. Vales et al. also performed subchronic studies with MWCNT, but in vitro on BEAS-2B cells. Reactive oxygen species (ROS)-level was measured together with comet assay and micronucleus (MN) test. They detected significant elevation in ROS level and MN frequency but primary DNA lesions (strand breaks) were not detected by the comet assay (21). The elevation of ROS level in different cells, tissues and organs upon MWCNT treatment was confirmed both in vitro $(22,23)$ and in vivo $(24,25)$ by several articles. In our previous in vivo (rat) studies involving urinary mutagenicity (Ames) test, sister chromatid exchange and MN analyses, SW- and MWCNT samples did not show any genotoxic effects (26).

The differences among the strains under study are obvious considering both the lymphocytes and macrophages. Wistar proved to be the most tolerant strain while F344 the more sensitive one. This latter showed the most significant effect in the present experiment.

Our results suggest that the physiological and biochemical (phenotypical) alterations originating from differences in the genetic strain may significantly affect the biological response to oral exposure to CNTs. In a previous experiment, peripheral white blood cell from LE and F344 rat strains and their F1 hybrids were studied (27). Phorbolester-induced superoxide production was significantly higher in the LE (vs. F344) strain, while their F1 hybrids behaved as F344. If differences are found in ROS production then differences in the protective processes (e.g. elevated activity of superoxide dismutase) may also occur. This can have considerable impact on the sensitivities of these strains to the indirect genotoxic effects of CNTs. 


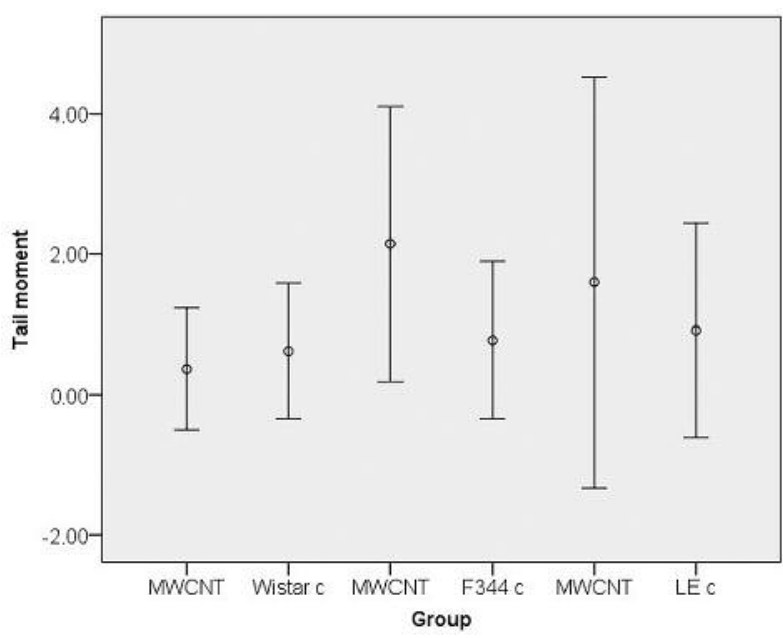

Figure 1. Levels of DNA lesions (tail moments) in lymphocytes from different rat strains $24 \mathrm{~h}$ after the first treatment with multi-walled carbon nanotubes (MWCNT). F344: Fischer-344, LE: Long-Evans, c: control. Data are the mean $\pm S D$.

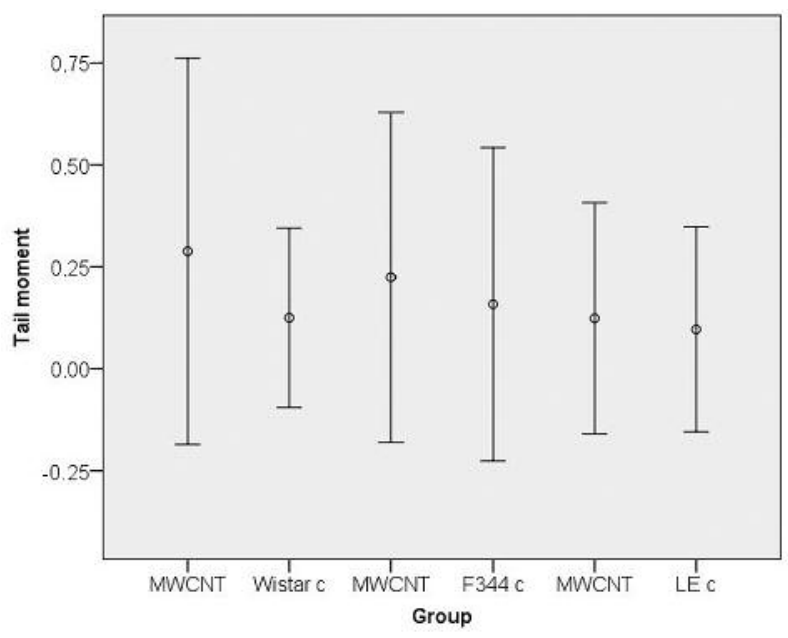

Figure 2. Levels of DNA lesions (tail moments) in lymphocytes from different rat strains 48 hours after the first treatment with multi-walled carbon nanotubes (MWCNT). F344: Fischer-344, LE: Long-Evans, c: control. Data are the mean $\pm S D$.

Furthermore, in lungs of humans and mice, MWCNT exposure exerts multifarious and overlapping effects on expression pattern of ubiquitous genes (matrix metalloprotinase-9, -12, -14; insulin-like growth factor-1, interleukins, etc.) which are involved in inflammatory as well as carcinogen signal transmission (28). Apart from attributes of the nanotubes, if the p53 gene is intact, it protects cells from malignant transformation by activating an inflammatory response (29), as well as preventing

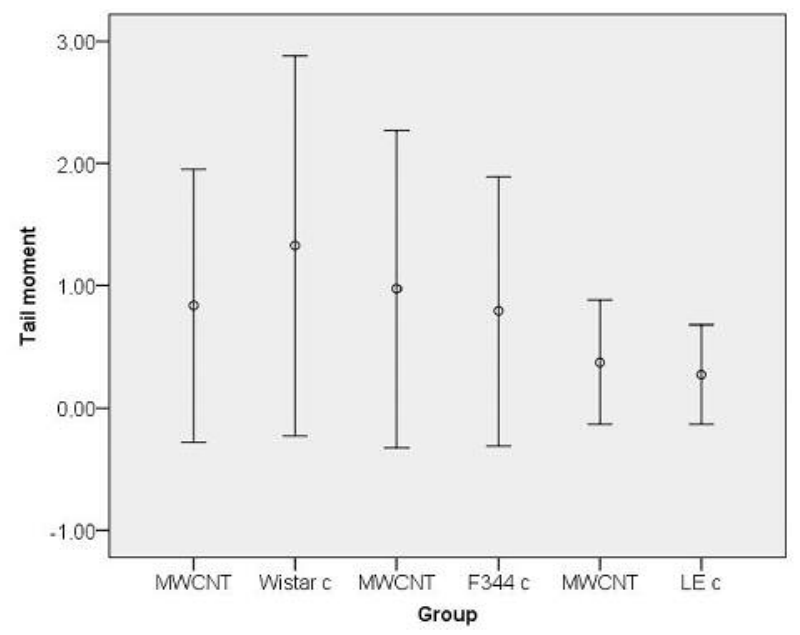

Figure 3. Levels of DNA lesions (tail moments) in lymphocytes from different rat strains at the 90th day of treatment with multi-walled carbon nanotubes (MWCNT). F344: Fischer-344, LE: Long-Evans, c: control. Data are the mean $\pm S D$.

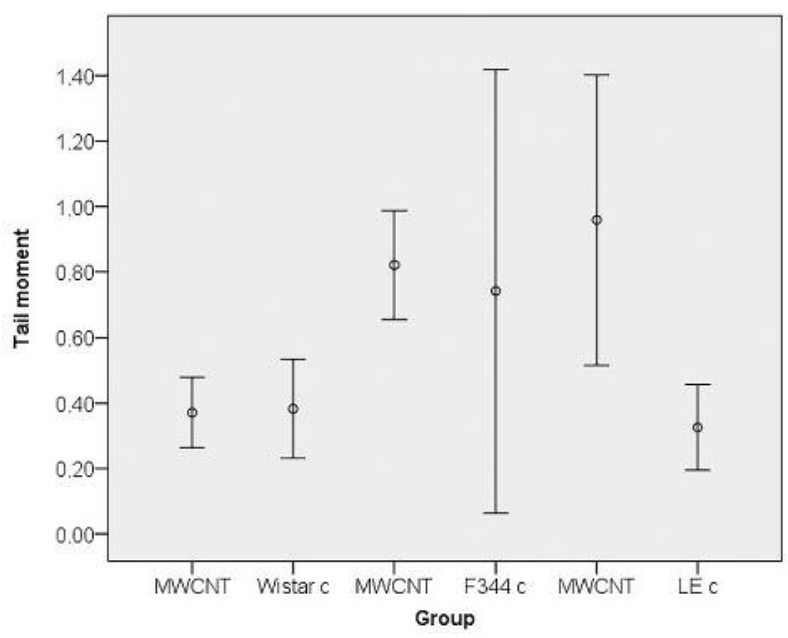

Figure 4. Levels of DNA lesions (tail moments) in peritoneal macrophages from different rat strains at the 90th day of treatment with multi-walled carbon nanotubes (MWCNT). F344: Fischer-344, LE: Long-Evans, c: control. Data are the mean $\pm S D$.

foetotoxicity (30). Indeed, p53 gene expression level corresponds to specific gene (Ha-ras, c-myc) expression patterns involved in early steps of carcinogenesis $(30,31$, 32 ). On the other hand, specific lipoxygenase and cyclooxygenase enzyme families not only take part in inflammatory pathways mediated by arachidonic acid metabolism but also overlap with carcinogenesis (33). Even chemopreventive agents (protodioscin, diosgenin, etc.) are capable of ameliorating deleterious effects of specific 
environmental carcinogens (e.g. dimethylbenz $[\alpha]$ anthracene) while reducing inflammatory response gene expression (33), and $\mathrm{N}$-acetylcysteine (NAC) as antioxidant prevented CNTinduced nuclear DNA damage, as well as foetotoxicity (30).

This latter possibility may have human relevance as well, that is, enhanced (or decreased) vulnerability of human populations with diverse gene pools to environmental nanotube exposure. There may be alterations in enzyme activities or DNA repair capacities, or different permeability of the gut wall.

Our subchronic experiment proved migration of ingested CNTs from the gut into the circulation, and that CNTs in the gastrointestinal system affected blood cells indirectly. Their impact on DNA - with a highly sensitive method- can be observed within the first $24 \mathrm{~h}$ of CNT administration.

\section{Acknowledgements}

The present scientific contribution is dedicated to the 650th anniversary of the foundation of the University of Pécs, Hungary. This work was financially supported by the Medical School, University of Pécs (PTE ÁOK-KA-2016/34039).

\section{References}

1 Bradley EL, Castle L and Chaudhry Q: Applications of nanomaterials in food packaging with a consideration of opportunities for developing countries. Trends Food Sci Technol 22: 604-610, 2011.

2 Zhang Y, Petibone D, Xu Y, Mahmood M, Karmakar A, Casciano D, Ali S and Biris AS: Toxicity and efficacy of carbon nanotubes and graphene: the utility of carbon-based nanoparticles in nanomedicine. Drug Metab Rev 46: 232-246, 2014.

3 Titirici MM, White RJ, Brun N, Budarin VL, Su DS, delMonte F, Clark JH and MacLachlan MJ: Sustainable carbon materials. Chem Soc Rev 44: 250-290, 2015.

4 Mundra RV, Wu X, Sauer J, Dordick JS and Kane RS: Nanotubes in biological applications. Curr Opin Biotechnol 28: 25-32, 2014.

5 Gottschalk $F$ and Nowack B: The release of engineered nanomaterials to the environment. J Environ Monit 13: 11451155,2011

6 Nowack B, David RM, Fissan H, Morris H, Shatkin JA, Stintz $\mathrm{M}$, Zepp R and Brouwer D: Potential release scenarios for carbon nanotubes used in composites, Environ Int 59: 1-11, 2013.

7 Silvestre C, Duraccio D, Cimmino S: Food Packaging Based on Polymer Nanomaterials. Progress in Polymer Science 36: 17661782, 2011.

8 Sargent LM, Hubbs AF, Young SH, Kashon ML, Dinu CZ, Salisbury JL, Benkovic SA, Lowry DT, Murray AR, Kisin ER, Siegrist KJ, Battelli L, Mastovich J, Sturgeon JL, Bunker KL, Shvedova AA and Reynolds SH: Single-walled carbon nanotubeinduced mitotic disruption. Mutat Res 745: 28-37, 2012.

9 Ghosh M, Chakraborty A, Bandyopadhyay M and Mukherjee A: Multi-walled carbon nanotubes (MWCNT): induction of DNA damage in plant and mammalian cells. J Hazard Mater 197: 327$336,2011$.
10 Cavallo D, Fanizza C, Ursini CL, Casciardi S, Paba E, Ciervo A, Fresegna AM, Maiello R, Marcelloni AM, Buresti G, Tombolini F, Bellucci $\mathrm{F}$ and Iavicoli S: Multi-walled carbon nanotubes induce cytotoxicity and genotoxicity in human lung epithelial cells. J Appl Toxicol 32: 454-464, 2012.

11 Lindberg H K, Falck GC, Singh R, Suhonen S, Järventaus H, Vanhala E, Catalán J, Farmer PB, Savolainen KM and Norppa H: Genotoxicity of short single-wall and multi-wall carbon nanotubes in human bronchial epithelial and mesothelial cells in vitro. Toxicology 313: 24-37, 2013.

12 Kato T, Totsuka Y, Ishino K, Matsumoto Y, Tada Y, Nakae D, Goto S, Masuda S, Ogo S, Kawanishi M, Yagi T, Matsuda T, Watanabe $\mathrm{M}$ and Wakabayashi K: Genotoxicity of multi-walled carbon nanotubes in both in vitro and in vivo assay systems. Nanotoxicology 7: 452-461, 2013.

13 Sargent LM, Hubbs AF, Young SH, Kashon ML, Dinu CZ, Salisbury JL, Benkovic SA, Lowry DT, Murray AR, Kisin ER, Siegrist KJ, Battelli L, Mastovich J, Sturgeon JL, Bunker KL, Shvedova AA and Reynolds SH: Single-walled carbon nanotubeinduced mitotic disruption. Mutat Res 745: 28-37, 2012.

14 IARC Monographs on the evaluation of carcinogenic risk to chemicals on Man. Vol 14: Asbestos. Lyon, IARC, pp 1-106, 1977.

15 Takagi A, Hirose A, Futakuchi M, Tsuda H and Kanno J: Dosedependent mesothelioma induction by intraperitoneal administration of multi-wallcarbon nanotubes in p53 heterozygous mice. Cancer Sci 103: 1440-1444, 2012.

16 Muller J, Delos M, Panin N, Rabolli V, Huaux F and Lison D: Absence of carcinogenic response to multiwall carbon nanotubes in a 2-year bioassay in the peritoneal cavity of the rat. Toxicol Sci 110: 442-448, 2009.

17 Varga $C$ and Szendi K: Carbon nanotubes induce granulomas but not mesotheliomas. In Vivo 24: 153-156, 2010.

18 Murray AR, Kisin ER, Tkach AV, Yanamala N, Mercer R, Young SH, Fadeel B, Kagan VE and Shvedova AA: Factoring-in agglomeration of carbon nanotubes and nanofibers for better prediction of their toxicity versus asbestos. Part Fibre Toxico 9: $10,2012$.

19 Szendi K and Varga C: Lack of genotoxicity of carbon nanotubes in a pilot study. Anticancer Res 28: 349-52, 2008.

20 Varga C, Horvath G and Timbrell V: On the mechanism of cogenotoxic action between ingested amphibole asbestos fibres and benzo[a]pyrene: II. Tissue specificity studies using comet assay. Cancer Lett 139: 173-117, 1999.

21 Valesa G, Rubioa L and Marcos R: Genotoxic and celltransformation effects of multi-walled carbon nanotubes (MWCNT) following in vitro sub-chronic exposures. J Hazard Mater 306: 193-202, 2016.

22 Jiang Y, Zhang H, Wang Y, Chen M, Ye S, Hou Z and Ren L: Modulation of apoptotic pathways of macrophages by surfacefunctionalized multi-walled carbon nanotubes. PLoS One 8(6): e65756, 2013.

23 Zhang T, Tang M, Kong L, Li H, Zhang T, Xue Y and Pu Y: Surface modification of multiwall carbon nanotubes determines the pro-inflammatory outcome in macrophage. J Hazard Mater 284: 73-82, 2015.

24 Patlolla A K, Berry A and Tchounwou PB: Study of hepatotoxicity and oxidative stress in male Swiss-Webster mice exposed to functionalized multi-walled carbon nanotubes. Mol Cell Biochem 358: 189-199, 2011. 
25 Poulsen SS, Saber AT, Williams A, Andersen O, Købler C, Atluri R, Pozzebon ME, Mucelli SP, Simion M, Rickerby D, Mortensen A, Jackson P, Kyjovska ZO, Mølhave K, Jacobsen NR, Jensen KA, Yauk CL, Wallin H, Halappanavar S and Vogel $\mathrm{U}$ : MWCNTs of different physicochemical properties cause similar inflammatory responses, but differences in transcriptional and histological markers of fibrosis in mouse lungs. Toxicol Appl Pharmacol 284: 16-32, 2015.

26 Szendi K and Varga C: Lack of genotoxicity of carbon nanotubes in a pilot study. Anticancer Res 28: 349-352, 2008.

27 Szücs S, Varga C, Ember I and Kertai P: The separation of the granulocytes from different rat strains. A comparative study. $\mathrm{J}$ Immuno Methods 167: 245-251, 1994

28 Guo NL, Wan Y, Denvir J, Porter DW, Pacurari M, Wolfarth MG, Castranova V and Qian Y: Multi-walled carbon nanotubeinduced gene signatures in the mouse lung: potential predictive value for human lung cancer risk and prognosis. J Toxicol Environ Health A 75: 1129-1153 2012.

29 Muller J, Delos M, Panin N, Rabolli V, Huaux F and Lison D: Absence of carcinogenic response to multi-wall carbon nanotubes in a 2-year bioassay in the peritoneal cavity of the rat. Toxicol Sci doi: 10.1093/toxsci/kfp100. 2016.

30 Huang X, Zhang F, Sun X, Choi KY, Niu G, Zhang G, Guo J, Lee $S$ and Chen $X$ : The genotype-dependent influence of functionalized multiwalled carbon nanotubes on fetal development. Biomaterials 35: 856-865, 2014.
31 Budán F, Varjas T, Nowrasteh G, Varga Zs, Boncz I, Cseh J, Prantner I, Tibold A, Pázsit E, Góbel Gy, Bauer M, Garacza T, Perjési P, Ember I and Gyöngyi Z: Early modification of c-myc, Ha-ras and p53 expressions by $N$-methyl- $N$-nitrosourea. In Vivo 22: 793-798, 2008.

32 Budán F, Varjas T, Nowrasteh G, Varga Zs, Ember Á, Cseh J, Prantner I, Gombos K, Pázsit E, Gőbel Gy, Bauer M, Garacza T, Arany I, Perjési P, Ember I and Kiss I: Early Modification of c-myc, Ha-ras and p53 expressions by chemical carcinogens (DMBA, MNU). In Vivo 23: 591-598. 2009.

33 Varjas T, Nowrasteh G, Budán F, Horváth G, Cseh J, Gyöngyi Z, Makai S and Ember I: The effect of fenugreek on the gene expression of arachidonic acid metabolizing enzymes. Phytother Res 25: 221-227, 2011.
Received June 30, 2016

Revised July 26, 2016

Accepted July 29, 2016 